\title{
Effect of Supplementation of Probiotic (Bacillus subtilis) on Growth Performance and Carcass Traits of Broiler Chickens
}

\author{
Manoj Yadav, Meenu Dubey, Maousami Yadav* and Karnam Shiv Shankar \\ Department of Animal Nutrition, College of Veterinary Science and Animal Husbandry, \\ Anjora, Chhattisgarh Kamdhenu Vishwavidyalaya Durg (C.G.), India \\ *Corresponding author
}

\begin{tabular}{|c|}
\hline Keywords \\
\hline $\begin{array}{l}\text { Probiotic, Bacillus } \\
\text { subtilis, growth } \\
\text { performance, carcass } \\
\text { traits, broiler }\end{array}$ \\
\hline Article Info \\
\hline $\begin{array}{l}\text { Accepted: } \\
28 \text { July } 2018 \\
\text { Available Online: } \\
10 \text { August } 2018\end{array}$ \\
\hline
\end{tabular}

\section{A B S T R A C T}

This study was conducted to find out the efficacy of probiotic (Bacillus subtilis) on growth performance and carcass traits of broiler birds. The experiment followed completely randomized design in which the day old broiler chicks $(\mathrm{n}=180)$ were divided into 4 dietary treatment groups $\left(\mathrm{T}_{1}-\mathrm{T}_{4}\right)$ as 3 replicates of 15 chicks in each. The chicks of four different groups were fed with basal diet, antibiotic growth promoter (Enramycin @ $250 \mathrm{mg} / \mathrm{kg}$ feed) and commercial probiotic containing 3 strains of Bacillus subtilis (DM 03, TAM 4 and IQB 350) spores at the concentration of $1 / 2$ million $/ g$ and 1 million/g of finished feed, respectively. The productive indicators evaluated were: body weight, feed consumption and feed conversion ratio (FCR). The carcass quality traits were also determined. The supplementation of Bacillus subtilis (1 miilion/g of finished feed) resulted in highly significant $(\mathrm{P}<0.01)$ increase in the body weight of birds as compare to control (T1) during $4^{\text {th }}$ and $5^{\text {th }}$ weeks of experiment. The feed consumption recorded lower in T4. The addition of Bacillus subtilis based probiotic and AGP showed highly significant $(\mathrm{p}<0.01)$ variation regarding weekly FCR during $3^{\text {th }}$ and $4^{\text {th }}$ week. The weight of liver, heart and intestine and the weight of different cuts (thigh, wing, and back) as percent of live weight accounted non-significant variations among different groups. However the weight of breast as per cent of live weight was highly significant $(\mathrm{P}<0.01)$ between the groups and found maximum in $\mathrm{T} 4$ group.

\section{Introduction}

Poultry are the cheapest source of animal protein, contributing significantly to supply the growing demand for animal food products around the world (Farrell, 2013). The consumption and trade in poultry products is increasing rapidly as the human population increases, making it the second largest source of meat after pork (FAO, 2014). The biggest challenge of commercial poultry production is the availability of quality feed on sustainable basis at stable prices. Probiotics (or direct fed microbials) are increasingly being popular as one of the alternatives to Antibiotic Growth Promoters (AGP). Probiotics can improve broiler chicken growth rates (Afsharmanesh and Sadaghi, 2014; Lei et al., 2015), it also helps in maintenance and establishment of intestinal micro biota beneficially that may enhance beneficial colonization in the GIT against pathogens. Supplementation of 
probiotics enhanced the growth rate in broilers better than AGP (Zhang and Kim, 2014) and other substitutes for AGP, such as phytochemicals e.g. essential oils (Khaksar et al., 2012). Probiotics are active against enteropathogens in several ways, including improved immunity-based elimination, competing for mucosal attachment and crucial nutrients, and producing antimicrobial complexes (Patel et al., 2015).

In broiler nutrition, probiotic species such as Lactobacillus, Streptococcus, Bacillus, Bifidobacterium, Enterococcus, Aspergillus, Candida, and Saccharomyces are widely used to prevent poultry pathogens and diseases and improve broiler's growth Performance. Bacillus species are superior probiotic feedadditives for poultry and pigs due to their big genomes with relevant features; they are spore producers which makes the product stable for long time and enhancing the bird's intestinal integrity and growth performance (Vazquez, 2016)). As a widely used probiotic strain, combination of Bacillus subtilis and Bacillus licheniformis are considered one of the most health-boosting bacteria because they have demonstrated a positive effect in aiding nutrient digestion and absorption in the host's body (Scgarrd and Demark, 1990).

In recent times, there has been significant progress in scientific evaluation and studies on probiotic Bacillus subtilis, revealing possible mechanisms of action like antimicrobial effect by synthesis of antimicrobial substances, antidiarrheal effect, immunostimulatory effect, competitive exclusion of pathogens, prevention of intestinal inflammation, and normalization of intestinal flora (Suva et al., 2016). Blanch et al., (2017) observed the addition of Bacillus subtilis DSM 17299 may efficiently compensate certain reductions of $\mathrm{ME}, \mathrm{CP}$ and amino acid in broiler diets supplemented with NSP-enzymes and phytase.

\section{Materials and Methods}

For this experiment the total growth period ( 0 to $6 \mathrm{wks}$ ) of broilers was divided into 3 phases pre starter (0-14 d), starter (14-21 d) and finisher $(21-42 \mathrm{~d})$. The pre starter diets contained $22 \% \mathrm{CP}$ and $3000 \mathrm{kcal} \mathrm{ME}$, starter $21.5 \% \mathrm{CP}$ and $3050 \mathrm{kcal} \mathrm{ME}$ and finisher diet contained $19.5 \% \mathrm{CP}$ and $3100 \mathrm{kcal} \mathrm{ME} / \mathrm{kg}$ feed. The diets were formulated using maize, deoiled soybean cake meal, dicalcium phosphate (DCP), limestone powder (LSP), soy oil, mineral and premixes containing trace minerals, vitamins and feed additives. The experiment was conducted to having completely randomized design. The day old broiler chicks $(n=180)$ were randomely allotted to 4 dietary treatment groups $\left(\mathrm{T}_{1}-\mathrm{T}_{4}\right)$. Each group had 3 replicates of 15 chicks in each i.e $3 * 15=45$ chicks/group. The chicks of group $\mathrm{T}_{1}$ (NC) were fed diet without any growth promoter (control), in $\mathrm{T}_{2}$ the chicks fed control diet supplemented with antibiotic growth promoter (Enramycin @ $250 \mathrm{mg} / \mathrm{kg}$ feed).

Chicks in group $T_{3}$ and $T_{4}$ were given control diet supplemented with commercial probiotic containing three strains of Bacillus subtilis (DM 03, TAM 4 and IQB 350). @ $11.5 \mathrm{~g}$ and $22.5 \mathrm{~g} / \mathrm{Q}$ feed respectively so as to get concentration of Bacillus subtilis spores will be $0.5 \mathrm{million} / \mathrm{g}$ and $1 \mathrm{million} / \mathrm{g}$ of finished feed in diets T3 and T4. The body weights of individual birds were recorded at weekly interval, and average body weight gain was calculated. Feed consumption of birds of each replicate was recorded at weekly intervals and feed consumption per bird per week and FCR were calculated. At the end of 6th week of age, three birds from each replicate were taken randomly for the recording of carcass characteristics. Birds were dressed, eviscerated and the dressed, eviscerated ready-to-cook and cut up yields were estimated. 


\section{Results and Discussion}

\section{Growth Performance}

The average body weight, weekly and cumulative weight gain of broiler chicks of different treatment groups is presented in the table 1 and 2, respectively. Results of the study have been grouped into three phases prestarter (0-14 days), starter (14-21days) and finisher (21-42 days).

\section{Pre - starter Phase (0-14 days)}

The supplementation of Bacillus subtilis based probiotic did not resulted in any significant variation in the weekly weight gain as compared to control and groups fed AGP supplemented diet during first $14 \mathrm{~d}$ of experiment. Similarly the cumulative body weight gains of birds of different dietary treatments at the end of pre starter phase were very close and did not vary significantly amongst the group (Table 2).

\section{Starter phase (14-21 days)}

The difference in average weekly body weight gain was highly significantly $(\mathrm{P}<0.01)$ amongst the treatment groups during the starter phase. Higher weight gain was recorded in broiler chicks received higher concentration of Bacillus subtilis spores (T4) as compare to other treatment groups.

Similarly the difference in cumulative weight gain was found to be highly significant $(\mathrm{P}<0.01)$ between treatment groups and control. Highest cumulative weight gain (844g) was recorded in the birds of group T4 and it was significantly $(\mathrm{P}<0.01)$ higher as compare to other groups.

The difference in cumulative weight gain was not significant between birds of groups T2 and $\mathrm{T} 3$ at the end of starter phase (21d).

\section{Finisher phase (21-42 days)}

A highly significant variation $(\mathrm{P}<0.01)$ were recorded with respect to weekly gain in body weight in the birds of all the three treatment groups as compared with the control group during $4^{\text {th }}$ week. However, there was nonsignificant $(\mathrm{P}>0.05)$ increase in the weight gain of experimental birds in treatment groups as compare to control during $5^{\text {th }}$ week of feeding trial. The highest weight gain was recorded in the birds T4 group (421.13g) followed by birds of group T3, T2 and T1 at the end of 42 day of study.

The difference in the cumulative weight gain of birds in group T2, T3 and T4 was significantly higher $(\mathrm{P}<0.01)$ during $4^{\text {th }}, 5^{\text {th }}$ and $6^{\text {th }}$ week.as compare to birds of control (T1) group. The cumulative weight gain of birds of group T4 was significantly $(\mathrm{P}<0.01)$ higher as compare to all other groups however CWG was comparable in birds of group T2 and T3 during $4^{\text {th }}$ and $5^{\text {th }}$ wk period. Cumulative weight gain of birds of T4 group at the end of $6^{\text {th }}$ week was significantly $(\mathrm{P}<0.05)$ higher as compare to birds of $\mathrm{T} 1$ and $\mathrm{T} 2$ groups.

In present experiment the cumulative weight gain was significantly high in the birds fed higher concentration of Bacillus subtilis spores as probiotics during starter and finisher stage and the findings are in agreement with Tournut (1998) who stated that the efficacy of probiotics depend on the quantitative and qualitative characteristics of microorganisms used in the production of probiotic growth promoters. Previous researcher Sabatkova et al., (2008) and Ahmad and Taghi (2006) also reported improvement in weight gain when broiler diet was supplemented with probiotics (Bacillus subtilis and Bacillus licheniformis) during 21-42 days period. The improvement in body weight gain due to supplementation of different starins of Bacillus subtilis based 
probiotics, in present experiment is associated with significantly better feed conversion ratio and also with significant increase in the height of villus and depth of crypt in duodenum of birds in these groups. In contrast to our findings Edens (2003) reported that the addition of a probiotic, with a predominance of Bacillus subtilis (Calsporin; Calpis Corporation, Tokyo, Japan) did not improve body weight (Calsporin $2416 \mathrm{~g}$ vs. control $2407 \mathrm{~g})$ at 42 days of age.

\section{Weekly and Cumulative Feed consumption}

The effect of supplementation of Bacillus subtilis based probiotic at two levels and AGP on average weekly and cumulative feed intake has been presented in table $3 \& 4$, respectively.

The average weekly feed intake due to supplementation of probiotics or AGP did not vary significantly amongst the treatment groups till $5^{\text {th }}$ week of experiment, though cumulative feed intake was significantly $(\mathrm{P}<0.05)$ low in group T3 (1918.11 g) as compare to groupd fed control and AGP supplemented diets (1971.44 \& $1985.36 \mathrm{~g}$, respectively). During $5^{\text {th }}$ and $6^{\text {th }}$ week of experiment the effect of supplementation of probiotics or AGP on weekly and cumulative feed intake was highly significant. The weekly feed intake was significantly $(\mathrm{P}<0.01)$ low in group fed probiotics in higher concentration (T4) as compare to other groups. Also the intake was significantly $(\mathrm{P}<0.01)$ low in group $\mathrm{T} 3$ as compare to $\mathrm{T} 2$ and $\mathrm{T} 1$, and also between groups $\mathrm{T} 1$ and $\mathrm{T} 2$ during $5^{\text {th }}$ and $6^{\text {th }}$ week of experiment. The cumulative feed intake at the end of finisher phase was significantly $(\mathrm{P}<0.01)$ low in groups fed probiotics supplemented diet irrespective of levels used as compare to control and AGP supplemented groups. Though the difference in cumulative feed intake between $\mathrm{T} 2$ and $\mathrm{T} 1$ was statistically comparable, it was numerically higher in $\mathrm{T} 1$ as compared to T2 (3719g v/s $3698 \mathrm{~g}$ )

Comparatively lower feed consumption observed in probiotic (Bacillus subtilis spores) supplemented group in present experiment is in agreement with the results reported by earlier researchers (Shim et al., 2012; Eseceli and Demir, 2010 and Erdogan, 2007) that supplementation of probiotic decreased the feed intake significantly $(\mathrm{P}<0.05)$ as compared to control group. Increased villus height and crypt depth in the birds of probiotics supplemented group improved the nutrient absorption and this may be the possibly reason for lower feed intake with improved growth performance in the birds of these groups.In contrast to our findings some researcher (Panda et al., 2008 and Rada et al., 2013) did not found significant difference in feed intake between control and probiotic supplemented groups.

\section{Weekly and cumulative Feed Conversion Ratio (FCR)}

The weekly FCR of birds of different treatment groups was statistically comparable during pre-starter phase. Cumulative feed conversion ratio was also comparable at the end of pre starter phase (0-14 day period). The effect of supplementation of probiotics on weekly feed conversion ratio and cumulative FCR at the end of starter phase was significantly $(\mathrm{P}<0.01)$ better in groups fed diet supplemented with probiotics irrespective of concentration as compare to birds fed control and AGP supplemented groups.

During $4^{\text {th }}$ week of experiment weekly and cumulative FCR was highly significantly $(\mathrm{P}<0.01)$ better in group fed higher concentration of Bacillus subtilis based probiotics (T4) amongst the treatment groups in which better weekly and cumulative FCR 
was also observed in birds of group $\mathrm{T} 3$ as compare to birds of $\mathrm{T} 2$ and $\mathrm{T} 1$ groups, however weekly and cummulative FCR between birds of group $\mathrm{T} 1$ and $\mathrm{T} 2$ was statistically comparable. During $5^{\text {th }}$ and $6^{\text {th }}$ week no significant effect of probiotics or AGP supplementation on weekly FCR was noticed (Table 5), however the difference in cumulative FCR at $4^{\text {th }}$ wk was highly significant amongst dietary groups (Table 6). At the end of $5^{\text {th }}$ week also the cumulative
FCR was significantly $(\mathrm{P}<0.01)$ better in birds fed higher concentration of Bacillus subtilis based probiotics (T4) (1.44) as compare to other groups; whereas at $6^{\text {th }}$ wk significantly $(\mathrm{P}<0.01)$ better cumulative FCR was reported in groups (T3, 1.59 and $\mathrm{T} 4,1.55)$ fed probiotics as compare to control and AGP supplemented groups. The difference in cumulative FCR in birds of T1 and T2 groups was statistically comparable during $5^{\text {th }}$ and $6^{\text {th }}$ week of age.

Table.1 Effect of supplementation of probiotic (Bacillus subtilis) and AGP (g/bird) on average weekly gain in body weight $(\mathrm{g})(\mathrm{Mean} \pm \mathrm{SE})$

\begin{tabular}{|c|c|c|c|c|c|}
\hline \multirow[t]{2}{*}{ Week } & \multicolumn{4}{|c|}{ Groups / Treatments } & \multirow[t]{2}{*}{ Sig. } \\
\hline & T1 & T2 & T3 & T4 & \\
\hline $1^{\text {st }}$ & $137.81 \pm 2.04$ & $137.40 \pm 1.23$ & $139.74 \pm 2.02$ & $140.33 \pm 0.87$ & NS \\
\hline $2^{\text {nd }}$ & $292.03 \pm 2.05$ & $292.81 \pm 1.88$ & $292.70 \pm 3.80$ & $290.67 \pm 3.43$ & NS \\
\hline $3^{\text {rd }}$ & $364.44 \pm 5.6^{\mathrm{a}}$ & $406.66 \pm 3.00^{b}$ & $405.67 \pm 5.48^{b}$ & $423.56 \pm 4.23^{\mathrm{c}}$ & ** \\
\hline $4^{\text {th }}$ & $587.58 \pm 3.72^{\mathrm{a}}$ & $581.47 \pm 2.02^{\mathrm{a}}$ & $582.83 \pm 4.46^{\mathrm{a}}$ & $625.43 \pm 12.19^{b}$ & ** \\
\hline $5^{\text {th }}$ & $406.74 \pm 3.10$ & $416.54 \pm 2.61$ & $414.68 \pm 6.69$ & $432.87 \pm 9.46$ & NS \\
\hline $6^{\text {th }}$ & $309.86 \pm 32.72$ & $319.06 \pm 28.45$ & $392.94 \pm 38.22$ & $421.13 \pm 23.53$ & NS \\
\hline
\end{tabular}

Superscripts are read row wise for comparison of means. Means in the same row with different superscripts a, $\mathrm{b}, \mathrm{c}$ are significantly different $*(\mathrm{P}<0.05), * *(\mathrm{P}<0.01), \mathrm{NS}=$ Non Significant.

Table.2 Effect of supplementation of probiotic (Bacillus subtilis) and AGP on cumulative gain in body weight $(\mathrm{g})$

\begin{tabular}{|c|c|c|c|c|c|}
\hline \multirow{2}{*}{$\begin{array}{c}\text { Days of } \\
\text { Observation }\end{array}$} & \multicolumn{4}{|c|}{ Groups / Treatments } & \multirow[t]{2}{*}{ Sig. } \\
\hline & T1 & T2 & T3 & T4 & \\
\hline 0-7 & $137.81 \pm 2.04$ & $137.40 \pm 1.23$ & $139.74 \pm 2.02$ & $140.33 \pm 0.87$ & NS \\
\hline 0-14 & $429.84 \pm 2.52$ & $430.21 \pm 2.54$ & $432.44 \pm 1.77$ & $431.00 \pm 3.01$ & NS \\
\hline $0-21$ & $794.28 \pm 3.47^{\mathrm{a}}$ & $836.88 \pm 3.05^{\mathrm{b}}$ & $838.11 \pm 4.70^{b}$ & $844.57 \pm 2.45^{\mathrm{c}}$ & $* *$ \\
\hline $0-28$ & $1381.86 \pm 5.84^{\mathrm{a}}$ & $1418.35 \pm 5.07^{b}$ & $1420.94 \pm 4.10^{b}$ & $1480.00 \pm 9.00^{c}$ & $* *$ \\
\hline $0-35$ & $1788.61 \pm 3.95^{\mathrm{a}}$ & $1834.89 \pm 4.49^{b}$ & $1835.63 \pm 2.66^{\mathrm{b}}$ & $1912.88 \pm 9.19^{c}$ & $* *$ \\
\hline $0-42$ & $2107.68 \pm 21.55^{\mathrm{a}}$ & $2144.76 \pm 26.57^{\mathrm{ab}}$ & $2256.76 \pm 35.57^{b c}$ & $2305.82 \pm 32.37^{\mathrm{c}}$ & * \\
\hline
\end{tabular}

Superscripts are read row wise for comparison of means. Means in the same row with different superscripts a, $\mathrm{b}, \mathrm{c}$ are significantly different $*(\mathrm{P}<0.05), * *(\mathrm{P}<0.01), \mathrm{NS}=$ Non Significant. 
Table.3 Effect of supplementation of probiotic (Bacillus subtilis) and AGP on average weekly feed consumption (g/bird)

\begin{tabular}{|c|c|c|c|c|c|}
\hline \multirow{2}{*}{ Week } & \multicolumn{4}{|c|}{ Groups / Treatments } & \multirow{2}{*}{ Sig. } \\
\cline { 2 - 6 } & $\mathbf{T 1}$ & $\mathbf{T 2}$ & $\mathbf{T 3}$ & $\mathbf{T 4}$ & \\
\hline $\mathbf{1}^{\text {st }}$ & $124.01 \pm 1.19$ & $130.56 \pm 3.36$ & $121.07 \pm 3.87$ & $129.12 \pm 2.41$ & NS \\
\hline $2^{\text {nd }}$ & $336.74 \pm 7.68$ & $328.02 \pm 8.62$ & $323.97 \pm 6.51$ & $322.79 \pm 6.62$ & NS \\
\hline $3^{\text {rd }}$ & $619.86 \pm 7.38$ & $657.59 \pm 6.83$ & $629.28 \pm 12.45$ & $630.51 \pm 8.03$ & NS \\
\hline $4^{\text {th }}$ & $890.81 \pm 3.05$ & $869.18 \pm 2.72$ & $843.77 \pm 15.23$ & $862.47 \pm 11.87$ & NS \\
\hline $5^{\text {th }}$ & $849.09 \pm 1.86^{\text {d }}$ & $835.09 \pm 1.85^{\text {c }}$ & $826.98 \pm 1.69^{\mathrm{b}}$ & $811.30 \pm 3.74^{\mathrm{a}}$ & $* *$ \\
\hline $\mathbf{6}^{\text {th }}$ & $898.71 \pm 2.88^{\mathrm{d}}$ & $877.82 \pm 2.44^{\mathrm{c}}$ & $861.73 \pm 5.06^{\mathrm{b}}$ & $837.87 \pm 3.21^{\mathrm{a}}$ & $* *$ \\
\hline
\end{tabular}

Superscripts are read row wise for comparison of means. Means in the same row with different superscripts a, $\mathrm{b}, \mathrm{c}, \mathrm{d}$ are significantly different $*(\mathrm{P}<0.05), * *(\mathrm{P}<0.01), \mathrm{NS}=$ Non Significant.

Table.4 Effect of supplementation of probiotic (Bacillus subtilis) on cumulative feed consumption $(\mathrm{g})$

\begin{tabular}{|c|c|c|c|c|c|}
\hline \multirow{2}{*}{$\begin{array}{c}\text { Days of } \\
\text { Observation }\end{array}$} & \multicolumn{4}{|c|}{ Groups / Treatments } & \multirow[t]{2}{*}{ Sig. } \\
\hline & T1 & $\mathbf{T} 2$ & T3 & T4 & \\
\hline $0-7$ & $124.01 \pm 1.19$ & $130.56 \pm 3.36$ & $121.07 \pm 3.87$ & $129.12 \pm 2.41$ & NS \\
\hline 0-14 & $460.76 \pm 8.84$ & $458.58 \pm 10.41$ & $445.05 \pm 6.42$ & $451.83 \pm 5.08$ & NS \\
\hline $0-21$ & $1080.62 \pm 10.64$ & $1116.17 \pm 13.84$ & $1074.33 \pm 11.83$ & $1082.35 \pm 5.86$ & NS \\
\hline $0-28$ & $1971.44 \pm 7.85^{\mathrm{b}}$ & $1985.36 \pm 12.51^{b}$ & $1918.11 \pm 10.83^{a}$ & $1944.82 \pm 6.01^{\mathrm{ab}}$ & $*$ \\
\hline 0-35 & $2820.50 \pm 5.99^{b}$ & $2820.46 \pm 15.30^{b}$ & $2745.10 \pm 16.83^{\mathrm{a}}$ & $2756.13 \pm 9.72^{\mathrm{a}}$ & $* *$ \\
\hline $0-42$ & $3719.25 \pm 3.22^{b}$ & $3698.28 \pm 13.97^{b}$ & $3606.83 \pm 14.99^{a}$ & $3594.00 \pm 12.86^{\mathrm{a}}$ & $* *$ \\
\hline
\end{tabular}

Superscripts are read row wise for comparison of means. Means in the same row with different superscripts a, $\mathrm{b}$ are significantly different $*(\mathrm{P}<0.05), * *(\mathrm{P}<0.01), \mathrm{NS}=$ Non Significant

Table.5 Effect of supplementation of probiotic (Bacillus subtilis) and AGP on weekly feed conversion ratio

\begin{tabular}{|c|c|c|c|c|c|}
\hline \multirow{2}{*}{ Week } & \multicolumn{4}{|c|}{ Sig. } \\
\cline { 2 - 6 } & $\mathbf{T 1}$ & $\mathbf{T 2}$ & $\mathbf{T 3}$ & $\mathbf{T 4}$ & \\
\hline $\mathbf{1}^{\text {st }}$ & $0.90 \pm 0.005$ & $0.95 \pm 0.017$ & $0.86 \pm 0.029$ & $0.92 \pm 0.011$ & NS \\
\hline $2^{\text {nd }}$ & $1.15 \pm 0.02$ & $1.12 \pm 0.03$ & $1.10 \pm 0.08$ & $1.11 \pm 0.01$ & NS \\
\hline $3^{\text {rd }}$ & $1.70 \pm 0.05^{\mathrm{c}}$ & $1.61 \pm 0.02^{\mathrm{b}}$ & $1.55 \pm 0.03^{\mathrm{ab}}$ & $1.48 \pm 0.08^{\mathrm{a}}$ & $* *$ \\
\hline $\mathbf{4}^{\text {th }}$ & $1.51 \pm 0.01^{\mathrm{c}}$ & $1.49 \pm 0.05^{\mathrm{c}}$ & $1.44 \pm 0.01^{\mathrm{b}}$ & $1.37 \pm 0.01^{\mathrm{a}}$ & $* *$ \\
\hline $\mathbf{5}^{\text {th }}$ & $2.08 \pm 0.01$ & $2.00 \pm 0.02$ & $1.99 \pm 0.03$ & $1.88 \pm 0.08$ & $\mathrm{NS}$ \\
\hline $\mathbf{6}^{\text {th }}$ & $2.82 \pm 0.6$ & $2.83 \pm 0.02$ & $2.05 \pm 0.1$ & $2.13 \pm 0.2$ & $\mathrm{NS}$ \\
\hline
\end{tabular}

Superscripts are read row wise for comparison of means. Means in the same row with different superscripts a, b,c are significantly different $*(\mathrm{P}<0.05), * *(\mathrm{P}<0.01), \mathrm{NS}=$ Non Significant 
Table.6 Effect of supplementation of probiotic (Bacillus subtilis) and AGP on cumulative feed conversion ratio

\begin{tabular}{|c|c|c|c|c|c|}
\hline \multirow{2}{*}{$\begin{array}{c}\text { Days of } \\
\text { Observation }\end{array}$} & \multicolumn{4}{|c|}{ Groups / Treatments } & \multirow{2}{*}{ Sig. } \\
\cline { 1 - 5 } & $\mathbf{T 1}$ & $\mathbf{T 2}$ & $\mathbf{T 3}$ & $\mathbf{T 4}$ & \\
\hline $\mathbf{0 - 7}$ & $0.90 \pm 0.05$ & $0.95 \pm 0.01$ & $0.86 \pm 0.02$ & $0.92 \pm 0.01$ & NS \\
\hline $\mathbf{0 - 1 4}$ & $1.07 \pm 0.01$ & $1.06 \pm 0.01$ & $1.02 \pm 0.03$ & $1.04 \pm 0.02$ & NS \\
\hline $\mathbf{0 - 2 1}$ & $1.36 \pm 0.01^{\mathrm{b}}$ & $1.33 \pm 0.01^{\mathrm{b}}$ & $1.28 \pm 0.01^{\mathrm{a}}$ & $1.26 \pm 0.04^{\mathrm{a}}$ & $* *$ \\
\hline $\mathbf{0 - 2 8}$ & $1.42 \pm 0.09^{\mathrm{c}}$ & $1.39 \pm 0.01^{\mathrm{c}}$ & $1.34 \pm 0.01^{\mathrm{b}}$ & $1.31 \pm 0.05^{\mathrm{a}}$ & $* *$ \\
\hline $\mathbf{0 - 3 5}$ & $1.57 \pm 0.03^{\mathrm{c}}$ & $1.53 \pm 0.08^{\mathrm{c}}$ & $1.49 \pm 0.08^{\mathrm{b}}$ & $1.44 \pm 0.01^{\mathrm{a}}$ & $* *$ \\
\hline $\mathbf{0 - 4 2}$ & $1.76 \pm 0.05^{\mathrm{b}}$ & $1.72 \pm 0.07^{\mathrm{b}}$ & $1.59 \pm 0.03^{\mathrm{a}}$ & $1.55 \pm 0.02^{\mathrm{a}}$ & $* *$ \\
\hline
\end{tabular}

Superscripts are read row wise for comparison of means. Means in the same row with different superscripts a, $\mathrm{b}, \mathrm{c}$ are significantly different $*(\mathrm{P}<0.05), * *(\mathrm{P}<0.01), \mathrm{NS}=$ Non Significant

Table.7 Effect of supplementation of probiotic (Bacillus subtilis) on carcass traits (\% of live weight) in broilers

\begin{tabular}{|l|c|c|c|c|c|}
\hline \multirow{2}{*}{ Particulars } & \multicolumn{4}{|c}{ Treatments } & \multirow{2}{*}{ Sig. } \\
\cline { 2 - 5 } & T1 & T2 & T3 & T4 & \\
\hline Dressed wt. & $73.52 \pm 2.19$ & $77.49 \pm 1.76$ & $79.92 \pm 1.73$ & $79.13 \pm 1.21$ & NS \\
\hline Liver & $1.77 \pm 0.15$ & $1.95 \pm 0.10$ & $1.80 \pm 0.11$ & $1.74 \pm 0.08$ & NS \\
\hline Heart & $0.49 \pm 0.05$ & $0.50 \pm 0.03$ & $0.56 \pm 0.05$ & $0.47 \pm 0.04$ & NS \\
\hline Intestine & $4.28 \pm 0.44$ & $4.66 \pm 0.24$ & $4.15 \pm 0.24$ & $4.86 \pm 0.26$ & NS \\
\hline Breast & $11.62 \pm 0.34^{\mathrm{a}}$ & $12.47 \pm 0.09^{\mathrm{ab}}$ & $13.31 \pm 0.33^{\mathrm{b}}$ & $15.31 \pm 0.72^{\mathrm{c}}$ & $* *$ \\
\hline Thigh & $20.36 \pm 0.09$ & $20.84 \pm 0.97$ & $21.36 \pm 0.44$ & $19.47 \pm 0.43$ & NS \\
\hline Wing & $15.84 \pm 1.26$ & $17.75 \pm 0.46$ & $19.94 \pm 1.13$ & $18.85 \pm 0.36$ & NS \\
\hline Giblet & $14.32 \pm 0.23$ & $13.66 \pm 0.37$ & $13.52 \pm 0.59$ & $12.88 \pm 0.27$ & NS \\
\hline Siblet & $4.72 \pm 0.10$ & $5.11 \pm 0.24$ & $4.76 \pm 0.19$ & $5.04 \pm 0.02$ & NS \\
\hline
\end{tabular}

Superscripts are read row wise for comparison of means. Means in the same row with different superscripts a, b,c are significantly different $*(\mathrm{P}<0.05), * *(\mathrm{P}<0.01), \mathrm{NS}=$ Non Significant

The significant beneficial effect of dietary supplementation of Bacillus subtilis spores on feed conversion ratio (FCR) of broiler during starter and finisher phase is in close agreement with the reports of previous researchers [Shim et al., (2012); Zhou et al., (2010) and Sabatkova et al., (2008)] who had reported that supplementation of broiler feed with Bacillus subtilis and B. licheniformis improved the feed conversion efficiency. Similarly, Panda et al., (2008) reported significantly better feed conversion efficiency in White Leghorn Breeders stock during (2540 wks of age of birds) with dietary inclusion of Bacillus subtilis and B. licheniformis (at the rate of $6 \times 10^{8}$ spores per $\mathrm{kg}$ of diet). In present study the cumulative FCR was significantly better in probiotics supplemented group as compare to AGP supplemented group during starter and finisher phase and these findings corroborate with Salim et al., (2013) who has reported better feed conversion ratio in broiler chicken fed diets with probiotic as compared to birds of antibiotic and control groups. The inclusion of desirable microorganisms (probiotics) in the diet allows the rapid development of beneficial bacteria in the digestive tract of the 
host, improving its performance (Edens, 2003). As a consequence, there is an improvement in the intestinal environment, increasing the efficiency of digestion and nutrient absorption processes (Pelicano et al., 2004), which may explain the improvement in cumulative feed conversion ratio observed in the present study during starter and finisher phase.

\section{Carcass traits}

The effect of supplementation of different concentration of Bacillus subtilis spores on carcass traits expressed as percentage of pre slaughter body weight of birds is presented in table 7 .

The average dressing percentage in slaughter birds, at the end of 42 days of feeding trial was $73.52 \pm 2.19,77.49 \pm 1.76,79.92 \pm 1.73$ and $79.13 \pm 1.21 \%$ for the groups $\mathrm{T} 1, \mathrm{~T} 2, \mathrm{~T} 3$ and $\mathrm{T} 4$ groups, respectively. In the present study a non-significant increase in the dressing percentage was found due to supplementation of probiotics and AGP as compare to control. The effect of dietary supplementation of Bacillus subtilis based probiotics and AGP on weight of internal organs viz. liver, heart and intestine was nonsignificant. The weight of different carcass cuts (thigh, wing, and back) as per cent of pre-slaughter weight differ non significantly amongst the group. However the weight of breast as per cent of live weight was significantly $(\mathrm{P}<0.01)$ high in the birds of group T4 $(15.31 \%)$ which were fed on diets supplemented with Bacillus subtilis spores@ 1 million/g of finished feed followed by T3 (13.31\%), T2 (12.47\%) and T1 (11.62\%) and difference between T3, T2 groups and T1 was statistically significant and T2 and T3 were comparable in this regard.

The results of present study indicated the beneficial effect of probiotic (Bacillus subtilis) supplementation @ 1 miillion /g of finished feed on some of the carcass characteristics of broiler, such as yield of breast meat. The findings corroborate with Molnar et al., (2013) who also reported that Bacillus species supplemented group had significantly $(\mathrm{P}<0.05)$ higher breast yield than the control group. Increased carcass yield, leg and breast weight was also reported by Kabir et al., (2004) and Farhoomand and Dadvend (2007). Whereas Mahmoud et al., (2017) did not found statistically significant difference in carcass yield between birds of probiotic supplemented group and control. In contrast Pelicano et al., (2003) observed that probiotic use in broiler diets lowered the dressed carcass and back yields and increased leg yield while wing and breast yield remained similar across treatment groups. Many reports indicated that the carcass weight increased by increasing the protein content of diet. Adding bacterial probiotic to diet enhanced the protein availability (Nahanshon et al., 1993), the numerical increase in the dressed carcass weight observed in the present study is probably due to increase in nitrogen retention as B. subtilis positively affect the ileal CP digestibility.

Probiotics containing different strains of Bacillus subtilis spores showed better results in terms of improved growth performance with better FCR as compared to antibiotic growth promoter. The dressing percentage of broiler birds was found non-significant higher due to supplementation of probiotics and AGP as compare to control. It can be concluded that Bacillus subtilis spores as probiotics are promising feed additive for growth performance and carcass quality in broilers.

\section{Acknowledgements}

The authors acknowledge the Dean, College of Veterinary Science and Animal Husbandry, Anjora, Durg and Dr, Devendra Dhar Dubey 
IB group Rajnandgaon for providing the facilities and support to this study.

\section{References}

Afsharmanesh, M.\&Sadaghi, B. 2014.Effects of dietary alternatives (probiotic, green tea powder and Kombucha tea) as antimicrobial growth promoters on growth, ileal nutrient digestibility, blood parameters, and immune response of broiler chickens. Comparative Clinical Pathology. 23(3): 717-724.

Ahmad $\mathrm{K}$ and $\mathrm{G}$ Taghi, 2006.Effect of probiotic on performance and immunocompetence in broilerchicks.Journal of Poultry Science, 43: 296-300.

Blanch, A., Rouault, M., Männer, K. andZentek, J. 2017. Efficacy of the dietary supplementation of a Bacillus subtilis-based probiotic on performance parameters of broiler chickens fed energy-, protein- and amino acidreduced diets, http://www.wpsa.com/index.php/wpsaproceedings/2017/21st-europeansymposium-on-poultry-nutrition/3242

Edens FW, 2003. An alternative for antibiotic use in poultry: Probiotics. RevistaBrasileira de Ciência Avícola, 5: 75-79.

Eseceli, H. and Demir, E. 2010.The effect of Bio-MosReg.

Mannan oligosaccharideand antibiotic growth promoter on performance of broiler.Journal of Animal and Veterinary Advances. 9(2): 392-395.

FAO [Food and Agriculture Organization of the United Nations]. 2014. Meat \& Meat Products. http://www.fao.org/ag/againfo/themes/e n/meat/home.html

Farhoomand, P., Dadvend, A., 2007. Carcass weight, growth performance and internal organ size of broilers fed $\begin{array}{ll}\text { graded } & \text { levels } \\ \text { Saccharomycesecerevisiae }\end{array}$ supplemented diets. Pakistan Journal of Biological Science. 10: 1870-1874

Farrell, D.2013. The role of poultry in human nutrition.

http://www.fao.org/docrep/013/al709e/ al709e00.

Kabir, S.M.L., Rahman, M.M., Rahman, M.B., Rahman, M. and Ahmed, S.U. 2004. The dynamics of probiotics on growth performance and immune response in broilers. International Journal of Poultry Science.3: 361-364

Khaksar, V., Golian, A. \& Kermanshahi, H. 2012. Immune response and ilealmicroflora in broilers fed wheatbased diet with or without enzyme Endofeed W and supplementation of thyme essential oil or probiotic PrimaLac. African Journal of Biotechnology. 11(81): 14716- 14723.

Lei, X., Piao, X., Ru, Y., Zhang, H., Péron, A. and Zhang, H. 2015. Effect of Bacillus amyloliquefaciens-based direct-fed microbial on performance, nutrient utilization, intestinal morphology and cecalmicroflora in broiler chickens. Asian-Australasian Journal of Animal Science. 28(2): 239-246.

Mahmoud, K.Z., Obeidata, B.S., Al-Sadia, M.Z. and Hatahet, Sh.R. 2017. Effect of Bacillus subtilis supplementation and dietary crude protein level on growth performance and intestinal morphological changes of meat type chicken. Livestock Science. 195: 99-104 Molnár, A.K., Podmaniczky, B., Kurti, P., Tenk, I., Glavits, R., Virag, G. Y. and Szabo, Z. S. 2011. Effect of different concentrations of Bacillus subtilis on growth performance, carcase quality, gut microflora, and immune response of broiler chickens. British Poultry Science. 52: 658-665. 
Nahanshon, S.N., Nakaue, H.S., and Mirosh, L.W. 1993. Effect of direct fed microbials on nutrient retention and production parameters of single white leghorn pullets. Poultry Science. 72: 87

Panda, A.K., Rama Rao, S.V., Raju M.V.L.N. and Sharma, S.R. 2006. Dietary supplementation of lactobacillus sporogenes on performance and serum biochemico-lipid profile of broiler chickens. Journal of Poultry Science. 43: 235-240.

Patel, S., Shukla, R. and Goyal, A., 2015. Probiotics in valorization of innate immunity across various animal models. Journal of Functional Foods. 14: 549561

Pelicano, E.R.L., Souza, P.D. and Oba, A. 2003. Effect of different probiotics on broiler carcass and meat quality. Rev. Bras. Cienc. Avic. 5(3): 207-214.

Rada, Foltyn, M., Lichovnikova, M. and Musilova, A. 2013. Effects of protease supplementation of low protein diets on growth parameters and carcass characteristics. Mendel Net pp: 268-272.

Sabatkova, J., Kumprecht, I. and Zobac, P. 2008 The probiotic Bio plus $2 \mathrm{~B}$ as an alternative of antibiotic in diets for broiler chickens. Acta Vet. Brno. 77: 569-574.

Shim, Y.H., Ingali, S.L., Kim, J.S., Seo, D.K., Lee, S.C. and Kwon, I.K. 2012. A multimicrobe probiotic formulation processed at low and high drying temperatures: effects on growth performance, nutrient retention and caecal microbiology of broilers. British Poultry Science. 53(4): 482-490.

Suva, M.A., Sureja, V.P. and Kheni, D.B. 2016. Novel insight on probiotic Bacillus subtilis: Mechanism of action and clinical applications. J Curr Res Sci Med. 2: 65-72

Tournut, J.R. 1998. Probiotics. In: $35^{\text {a }}$ Reunião Anual da Sociedade Brasileira de Zootecnia; 1998; Botucatu, São Paulo, Brasil. p. 179-199.

Vazquez, A.P. 2016. Bacillus species are Superior Probiotic Feed-Additives for Poultry. J Bacteriol Mycol Open Access. 2(3): 00023.

Zhang, Z. and Kim, I. 2014. Effects of multistrain probiotics on growth performance, apparent ileal nutrient digestibility, blood characteristics, cecal microbial shedding, and excreta odor contents in broilers. Poultry Science. 93(2): 364-370.

\section{How to cite this article:}

Manoj Yadav, Meenu Dubey, Maousami Yadav and Karnam Shiv Shankar. 2018. Effect of Supplementation of Probiotic (Bacillus subtilis) on Growth Performance and Carcass Traits of Broiler Chickens. Int.J.Curr.Microbiol.App.Sci. 7(08): 4840-4849.

doi: https://doi.org/10.20546/ijcmas.2018.708.510 